Journal of Materials and Environmental Sciences ISSN : 2028-2508

CODEN : JMESCN
J. Mater. Environ. Sci., 2018, Volume 9, Issue 1, Page 358-369

https://doi.org/10.26872/jmes.2018.9.1.39

http://www.jmaterenvironsci.com/

\title{
Evaluation of alkaloids extract of Retama monosperma (L.) Boiss. stems as a green corrosion inhibitor for carbon steel in pickling acidic medium by means of gravimetric, AC impedance and surface studies
}

\author{
R. Fdil ${ }^{1}$, M. Tourabi ${ }^{2}$, S. Derhali ${ }^{1}$, A. Mouzdahir ${ }^{1}$, k. Sraidi ${ }^{1}$, C. Jama ${ }^{3}$, \\ A. Zarrouk ${ }^{4}$, F. Bentiss ${ }^{2,3, *}$ \\ ${ }^{1}$ Laboratory of Bioorganic Chemistry, Faculty of Sciences, Chouaib Doukkali University, \\ B.P. 20, M-24000 El Jadida, Morocco \\ ${ }^{2}$ Laboratory of Catalysis and Corrosion of Materials, Faculty of Sciences, Chouaib Doukkali University, B.P. 20, M-24000 \\ El Jadida, Morocco \\ ${ }^{3}$ Univ. Lille, CNRS, INRA, ENSCL, UMR 8207, - UMET - Unit of Materials and Transformations, F-59000 Lille, France \\ ${ }^{4}$ LC2AME-URAC 18, Faculty of Science, First Mohammed University, PO Box 717, M-60000 Oujda, Morocco
}

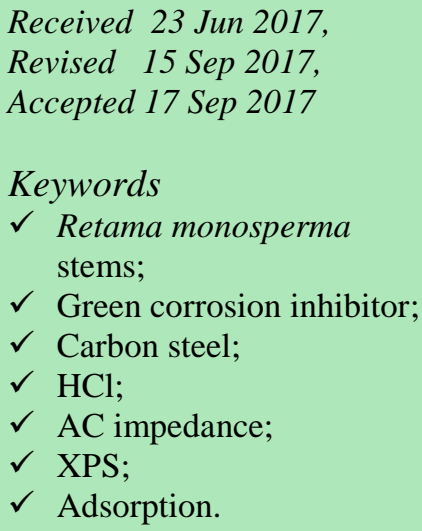

Received 23 Jun 2017,

Revised 15 Sep 2017,

Accepted 17 Sep 2017

\section{Bentiss Fouad} fbentiss@gmail.com

\begin{abstract}
The present work is devoted to the study of alkaloids extract from Retama monosperma stems (AERST) as green corrosion inhibitor to afford the protection of carbon steel in $1 \mathrm{M} \mathrm{HCl}$ medium at $30^{\circ} \mathrm{C}$. Weight loss and $\mathrm{AC}$ impedance techniques were coupled with Scanning Electron Microscopy (AERST) and X-Ray Photoelectron Spectroscopy (XPS) analyses to characterize the inhibitive properties of AERST and to determine the chemical composition of the inhibitive film formed on the steel surface. AERST inhibited the corrosion of carbon steel in $1 \mathrm{M} \mathrm{HCl}$, and its inhibition efficiency increased with the inhibitor concentration. However, a maximum inhibition efficiency of $83 \%$ was reached with $400 \mathrm{mg} / \mathrm{L}$ of AERST at $30^{\circ} \mathrm{C}$. Adsorption of AERST on the steel surface in $1 \mathrm{M} \mathrm{HCl}$ solution followed Langmuir's isotherm. The XPS studies showed that the inhibitive layer is composed of an iron oxide/hydroxide mixture where AERST molecules are incorporated.
\end{abstract}

\section{Introduction}

Iron and its alloys find extensive structural applications in industry and engineering construction, where they are used in a variety of service environments. The aggressive nature of some service environments often leads to excessive corrosion of exposed metal surfaces, which is a major cause for concern. A significant method for protecting such metals is the introduction of corrosion inhibitors that hinder the corrosion reaction and thus reduce the corrosion rate. Owing to increasing ecological awareness and strict environmental regulations, as well as the inevitable drive toward sustainable and environmentally friendly processes, attention is now focused on the development of nontoxic alternatives to inorganic and organic inhibitors applied earlier. Consequently, the current focus in corrosion inhibitor research is on identifying and developing new classes of nontoxic, benign, and inexpensive alternatives.

Some investigations have in recent times been made into the corrosion inhibiting properties of natural products of plant origin, and have been found to generally exhibit good inhibition efficiencies [1-11]. The significance of this area of research is primarily due to the fact that natural products are environmentally friendly and ecologically acceptable. The yield of these natural products as well as the corrosion inhibition abilities of the plant extracts vary widely depending on the part of the plant [12,13] and its location [14]. Of importance also is the specificity of corrosion inhibiting compounds. One compound effective in a certain medium with a given metal may be ineffective for the same metal in another medium [15]. 
In our continuous quest to explore more natural products of plant origin as corrosion inhibitors, the stems of Retama monosperma (L.) Boiss. was selected for this study. In our previous work on the seeds of Retama monosperma (L.) Boiss, the obtained alkaloids extract has been tested for the first time as corrosion inhibitor on mild steel in $1 \mathrm{M} \mathrm{HCl}$ [16]. The obtained results showed that the seeds extract is efficient corrosion inhibitor and a high value of inhibition efficiency was obtained even at lower concentration $(94.4 \%$ at $400 \mathrm{mg} / \mathrm{L})$. In a continuation of this programme, the present paper reports the detailed study of the inhibition effect of alkaloids extract from Retama monosperma stems (AERST) on the corrosion behaviour of carbon steel in normal hydrochloridric solution $(1 \mathrm{M} \mathrm{HCl})$ at $30^{\circ} \mathrm{C}$ using gravimetric and $\mathrm{AC}$ impedance methods. Adsorption isotherm, Scanning Electron Microscopy (SEM) and X-ray photoelectron spectroscopy (XPS) have been applied to study the mechanism of carbon steel corrosion inhibition of this essential oil in acidic medium.

\section{Experimental details}

\subsection{Materials}

The stems of Retama monosperma (L.) Boiss. were collected in the coastal dunes of Haouzia (El Jadida, Western Morocco) and the alkaloids extract was obtained according to a previously described experimental procedure [17]. The obtained constituent percentages of the Retama monosperma (L.) Boiss. stems extract are summarized in Table 1 and chemical structures of the major constituents of the extract are shown in Fig. 1.

Table 1. Chemical composition of Retama monosperma (L.) Boiss. Stems extract.

\begin{tabular}{cc}
\hline Alkaloid & $(\%)$ \\
\hline Sparteine & 28.87 \\
Dehydrosparteine & 9.40 \\
Ammodendrine & 24.36 \\
N-methylcytisine & 7.93 \\
Cytisine & 3.23 \\
17-Oxosparteine & 1.61 \\
Isolupanine & 5.25 \\
5,6-Dehydrolupanine & 7.05 \\
11,12-Dehydrolupanine & Trace \\
Anagyrine & 12.33 \\
\hline
\end{tabular}

The material used in this study is a carbon steel (Euronorm: C35E carbon steel and US specification: SAE 1035) with a chemical composition (in wt \%) of $0.370 \% \mathrm{C}, 0.230 \% \mathrm{Si}, 0.680 \% \mathrm{Mn}, 0.016 \% \mathrm{~S}, 0.077 \% \mathrm{Cr}, 0.011 \%$ $\mathrm{Ti}, 0.059 \% \mathrm{Ni}, 0.009 \% \mathrm{Co}, 0.160 \% \mathrm{Cu}$ and the remainder iron $(\mathrm{Fe})$. The steel samples were pre-treated prior to the experiments by grinding with emery paper $\operatorname{SiC}(120,600$ and 1200); rinsed with distilled water, degreased in acetone in an ultrasonic bath immersion for $5 \mathrm{~min}$, washed again with bidistilled water and then dried at room temperature before use. The acid solutions $(1 \mathrm{M} \mathrm{HCl})$ were prepared by dilution of an analytical reagent grade $37 \% \mathrm{HCl}$ with doubly distilled water. The solubility of the alkaloids extract of Retama monosperma stems (AERST) is about $1 \mathrm{~g} / \mathrm{L}$ in $1 \mathrm{M} \mathrm{HCl}$. The concentration range of AERST employed was in the range 50 to 400 $\mathrm{mg} / \mathrm{L}$.

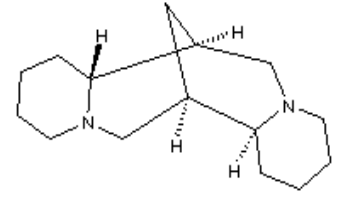

Sparteine (28.87\%)

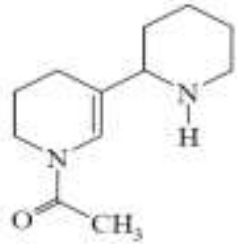

Ammodendrine (24.36 \%)

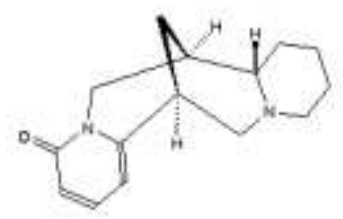

Anagyrine (12.33 \%)

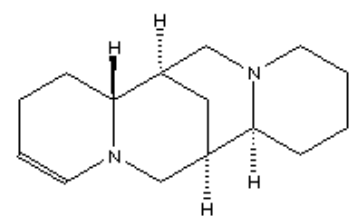

Dehydrosparteine $(9.40 \%)$

Figure 1: Chemical structures of the major constituents of Retama monosperma (L.) Boiss. stems extract

\subsection{Weight loss method}

Gravimetric experiments were performed according to the standard method "ASTM G 31-72" described previously [18]. Weight loss testing was developed on rectangular specimens with a size of $1.5 \mathrm{~cm} \times 1.7 \mathrm{~cm} \times 0.3 \mathrm{~cm}$. The weight of each specimen was measured before and after testing in the aggressive medium with an analytical balance (precision $\pm 0.1 \mathrm{mg}$ ). Gravimetric experiments were carried out in a double 
glass cell equipped with a thermostated cooling condenser containing $100 \mathrm{~mL}$ of non-de-aerated test solution. After the exposure time, the specimen was taken out and washed with double distilled water. The corrosion product on the steel surface was mechanically removed by rubbing it with a brush. The specimens were washed in an ultrasonic bath with acetone, dried under air flow, set in a dry off oven at $100{ }^{\circ} \mathrm{C}$, finally their weight loss were recorded. The experiments were done by triplicate and the average value of the weight loss was used to calculate the corrosion rate $\left(C_{\mathrm{R}}\right)$, in $\mathrm{mg} \mathrm{cm}^{-2} \mathrm{~h}^{-1}$ and the inhibition efficiency, $\eta_{\mathrm{wL}}(\%)$, in percent $(\%)$, as described previously [19]:

\subsection{AC impedance technique}

AC impedance tests were performed in a polymethyl methacrylate (PMMA) cell with a capacity of $1000 \mathrm{ml}$ at $30 \pm 1{ }^{\circ} \mathrm{C}$, using a thermostat. A saturated calomel electrode (SCE) was used as the reference; while a platinum leaf was used as a counter electrode. All potentials were reported $v s$. SCE. The working electrode was prepared from a square sheet of carbon steel such that the area exposed to solution was $7.55 \mathrm{~cm}^{2}$. All impedance spectra were recorded at the steady state of open circuit potential, i.e. at the corrosion potential, after $6 \mathrm{~h}$ of the exposure of the working electrode to the solution (no deaeration, no stirring). AC impedance measurements were performed using a potentiostat Solartron SI 1287 and a Solartron 1255B frequency response analyzer and ZPlot 2.80 software was used to run the tests and to collect the experimental data. The response of the electrochemical system to ac excitation with a frequency ranging from $10^{5} \mathrm{~Hz}$ to $10^{-2} \mathrm{~Hz}$ and peak to peak amplitude of $10 \mathrm{mV}$ was measured with data density of 10 points per decade. One EIS spectrum is recorded usually within 10 min. The impedance data were analysed and fitted with the simulation ZView 2.80, equivalent circuit software.

\subsection{Surface analyses}

Micrographs of the carbon steel surface before and after the immersion in $1 \mathrm{M} \mathrm{HCl}$ with and without corrosion inhibitor, coated by a film of $50 \mathrm{~nm}$ of gold by sputtering, were taken using Scanning Electron Microscopy (JEOL 5300). The energy of the acceleration beam employed was $6 \mathrm{kV}$.

X-ray photoelectron spectroscopy (XPS) spectra were recorded by an XPS KRATOS, AXIS Ultra ${ }^{\text {DLD }}$ spectrometer with the monochromatized Al-K $\alpha$ X-ray source $(h v=1486.6 \mathrm{eV})$ and an X-ray beam of around $1 \mathrm{~mm}$. The analyser was operated in constant pass energy of $40 \mathrm{eV}$ using an analysis area of approximately 700 $\mu \mathrm{m} \times 300 \mu \mathrm{m}$. Charge compensation was applied to compensate for the charging effects that occurred during the analysis. The $\mathrm{C} 1 s(285.0 \mathrm{eV})$ binding energy (BE) was used as internal reference. The spectrometer BE scale was initially calibrated against the $\mathrm{Ag} 3 d_{5 / 2}(368.2 \mathrm{eV})$ level. Pressure was in the $10^{-10}$ torr range during the experiments. Quantification and simulation of the experimental photopeaks were carried out using CasaXPS software. Quantification took into account a non-linear Shirley background subtraction [20].

\section{Results and discussion}

\subsection{Corrosion inhibition evaluation}

\subsubsection{Weight loss and SEM studies}

The corrosion rate $\left(C_{\mathrm{R}}\right)$ and the inhibition efficiency, $\eta_{\mathrm{WL}}(\%)$, values obtained from weight loss method at different concentrations of AERST after $6 \mathrm{~h}$ of immersion in $1 \mathrm{M} \mathrm{HCl}$ at $30^{\circ} \mathrm{C}$ are compiled in Table 2.

Table 2. Corrosion parameters obtained from weight loss measurements for carbon steel in $1 \mathrm{M} \mathrm{HCl}$ containing various concentrations of AERST at $30{ }^{\circ} \mathrm{C}$.

\begin{tabular}{cccc}
\hline Inhibitor & Concentration $(\mathrm{mg} / \mathrm{L})$ & $C_{\mathrm{R}}\left(\mathrm{mg} \mathrm{cm}^{-2} \mathrm{~h}^{-1}\right)$ & $\eta_{\mathrm{wL}}(\%)$ \\
\hline Blank & - & $2.50 \pm 0.05$ & - \\
\hline \multirow{2}{*}{ AERST } & 50 & $1.51 \pm 0.03$ & $39.7 \pm 0.3$ \\
& 100 & $0.59 \pm 0.03$ & $76.5 \pm 0.3$ \\
& 200 & $0.54 \pm 0.02$ & $78.3 \pm 0.2$ \\
& 300 & $0.46 \pm 0.01$ & $81.6 \pm 0.1$ \\
& 400 & $0.42 \pm 0.01$ & $83.1 \pm 0.1$ \\
\hline
\end{tabular}

It is evident from this Table that, with gradually increased inhibitor concentrations, the corrosion rate $\left(C_{\mathrm{R}}\right)$ of carbon steel decreases gradually, i.e. the corrosion of steel is retarded by AERST, while the inhibition efficiency enhances with the inhibitor concentration and the maximum value of $\eta_{\mathrm{WL}}(\%)$ is achieved at $400 \mathrm{mg} / \mathrm{L}$. Indeed, the inhibitive effect of AERST versus concentration, presented in Fig. 2, shows that the $\eta_{\mathrm{wL}}$ increases sharply 
with the concentration when the concentration of AERST is less than $200 \mathrm{mg} / \mathrm{L}$ whereas it show slight increase of $\eta_{\mathrm{WL}}$ as AERST concentration increases from 200 to $300 \mathrm{~g} / \mathrm{L}$. When the inhibitor concentration is up to 300 $\mathrm{g} / \mathrm{L}$, the $\eta_{\mathrm{WL}}$ reaches $83.1 \%$ at $400 \mathrm{mg} / \mathrm{L}$ of AERST and then any significant increase in inhibition efficiency was observed. The corrosion inhibition property of AERST can be attributed to the adsorption of the AERST molecules (Sparteine, Ammodendrine...) at the carbon steel surface.

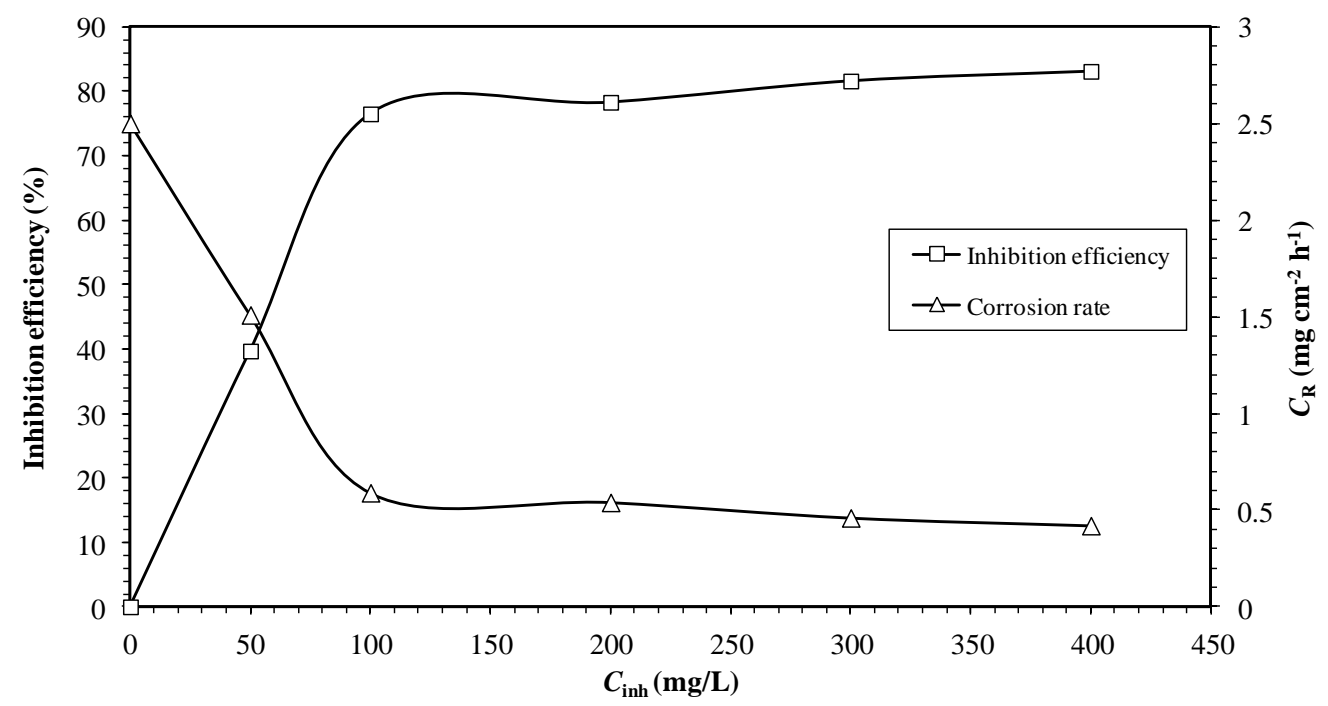

Figure 2: Relationship between corrosion inhibition efficiency $\left(\eta_{\mathrm{WL}}\right)$, corrosion rate $\left(C_{\mathrm{R}}\right)$ of carbon steel in $1 \mathrm{M}$ $\mathrm{HCl}$ and concentration of AERST
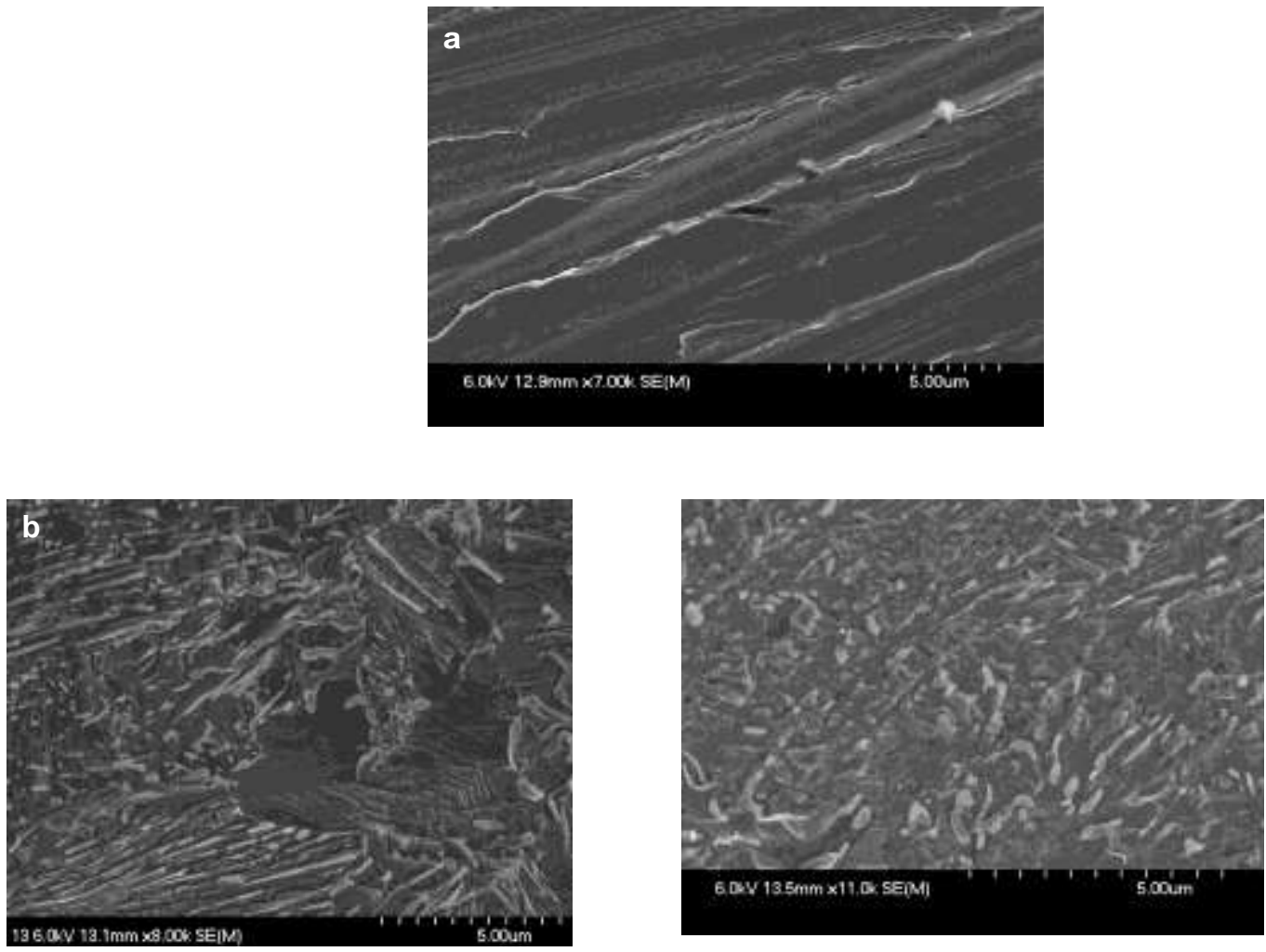

Figure 3: SEM micrographs of the carbon steel surface: a) Metallic surface after being polished, b) metallic surface after 6 $\mathrm{h}$ immersion in $1 \mathrm{M} \mathrm{HCl}$ and c) metallic surface after $6 \mathrm{~h}$ immersion in $1 \mathrm{M} \mathrm{HCl}$ with $400 \mathrm{mg} / \mathrm{L}$ of AERST

The scanning electron microscopy (SEM) micrographs (Figs. $3 \mathrm{a}-\mathrm{c}$ ) of the surfaces of carbon steel strips were recorded in order to see the changes occurred during corrosion process in absence and presence of AERST. Fig. 4 shows the SEM micrographs of the carbon steel surface before and after of the immersion in $1 \mathrm{M} \mathrm{HCl}$ with and without corrosion inhibitor. Parallel features on the polished steel surface before exposure to the corrosive solution are clearly visible, which are associated with abrading scratches (Fig. 3a). Figs. 3b and 3c show the steel surface after $6 \mathrm{~h}$ of immersion in $1 \mathrm{M} \mathrm{HCl}$ without and with addition of AERST. The resulting of 
the high resolution SEM micrograph (Fig. 3b) shows that the steel surface was strongly damaged in $1 \mathrm{M} \mathrm{HCl}$ solution without inhibitor with the increased number and depth of the pits due to rapid corrosion attack. However, a relatively smoother and less corroded morphology of steel surface can be observed in the micrographs in the presence of AERST (Fig. 3c). This shows that AERST inhibits the carbon steel corrosion in $1 \mathrm{M} \mathrm{HCl}$ by the formation of a protective inhibitive film on the steel surface. Indeed, AERST has a strong tendency to adhere to the steel surface and can be regarded as good inhibitor for steel corrosion in normal hydrochloric medium. The good inhibitive performance of this inhibitor suggests a strong bonding of the AERST constituents on the metal surface due to presence of lone pairs from heteroatom (nitrogen, oxygen) and $\pi$-orbitals, blocking the active sites and therefore decreasing the corrosion rate. Also, the inhibitive nature of the AERST may be attributed to the synergistic intermolecular effect of the different active constituents present in Retama monosperma (L.) Boiss. stems extract (Table 1, Fig. 1).

\subsubsection{AC impedance study}

The corrosion inhibition property of AERST on carbon steel was also examined by electrochemical impedance spectroscopy (EIS). An impedance measurement is a veritable tool and has been widely used in investigating corrosion inhibition processes. It provides information on both the resistive and capacitive behaviour at interface and makes it possible to evaluate the performance of the tested compounds as possible inhibitors against metals' corrosion. Electrochemical impedance spectroscopy experiments were carried out on a newly polished steel surface in acidic solution without and with addition of DAPO at open circuit potential after $6 \mathrm{~h}$ of immersion in $1 \mathrm{M} \mathrm{HCl}$ solution at $30^{\circ} \mathrm{C}$. Figs. 4-6 show the impedance spectra as Nyquist and Bode plots, respectively obtained for carbon steel in absence and presence of different concentrations of AERST.
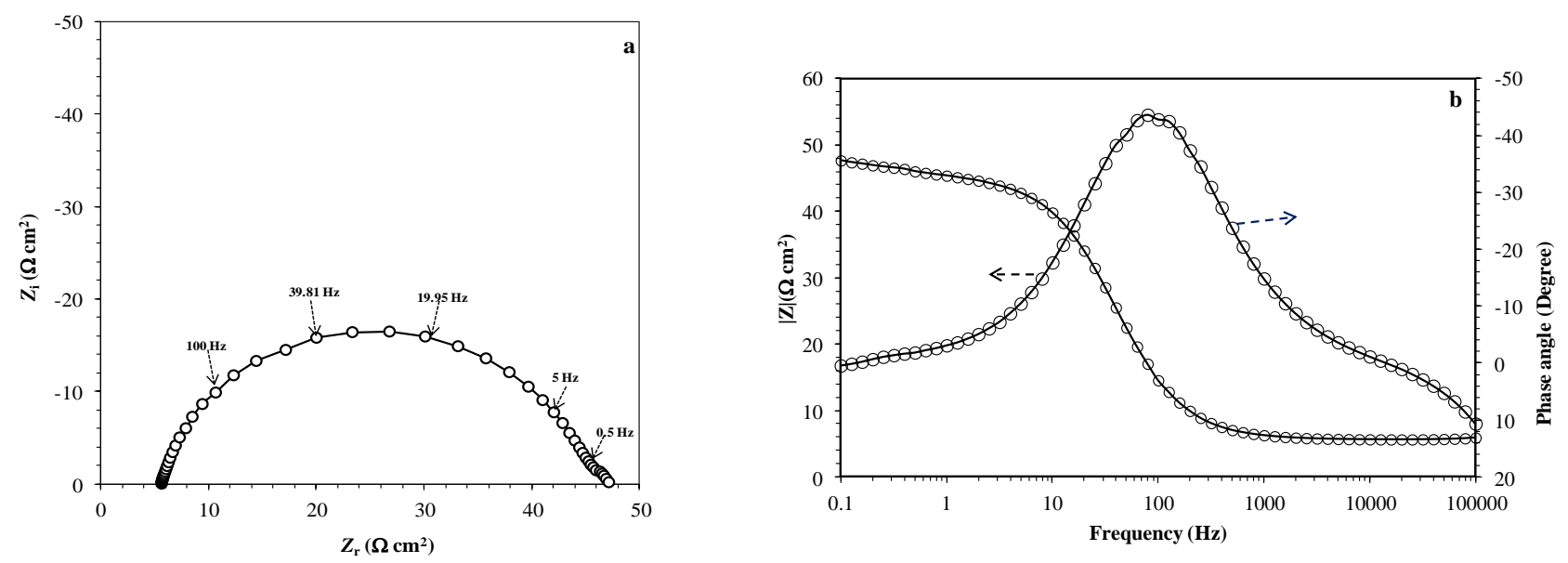

Figure 4: Nyquist (a) and Bode (b) diagrams for carbon steel in $1 \mathrm{M} \mathrm{HCl}$ after $6 \mathrm{~h}$ of immersion period at $30^{\circ} \mathrm{C}$

The Nyquist plots show a single depressed capacitive semicircle for both inhibited and uninhibited solutions, with one capacitive time constant in the Bode-phase plots. The depressed semicircle in Nyquist diagrams is characteristic of solid electrodes that exhibit frequency dispersion due to the roughness and other inhomogeneities of the surface [21,22]. Also, the slopes of the Bode-modulus plots $(\log |Z|$ vs $\log f)$ are not equal to -1 (Figs. 4b and 6), which are commonly observed for solid electrodes as a result of frequency dispersion of interfacial impedance. The capacitive loop is usually associated with charge transfer process and electrical double layer. The addition of different concentrations of AERST does not substantially change the shape of the semicircle indicating that the inhibitor addition does not change the mechanism of corrosion reaction but inhibits the corrosion by increasing the surface coverage by the adsorbed inhibitor film [23]. As shown in Figs. 4a and 5, the diameter of the capacitive loop in the presence of AERST is larger than that in the uninhibited system and increases with increase in concentration of the inhibitor. The same behaviour is shown on the Bodemodulus plots (Figs. 4b and 6). Indeed, the global impedance modulus at $0.1 \mathrm{~Hz}$ was determined and was $26 \Omega$ $\mathrm{cm}^{2}$ for uninhibited solution and 67.21, 171.82, 178.53, 222, and $224.93 \Omega \mathrm{cm}^{2}$ after addition of 50, 100, 200, 300 and 400 of AERST, respectively. Also, the Bode-phase angle plots (Fig. 6) clearly show that the maximum phase angle increases with increasing of AERST concentration, which indicates the increase of capacitive response with AERST concentration [23]. Such a phenomenon could be related to adsorption of the inhibitor on the steel surface [24]. 


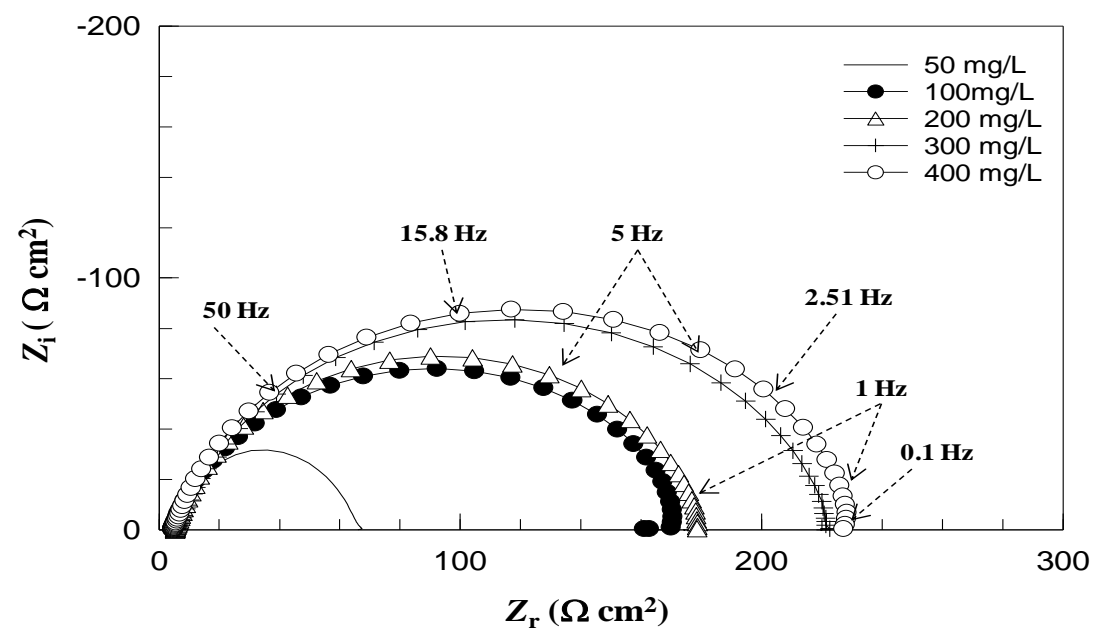

Figure 5: Nyquist diagrams for carbon steel in $1 \mathrm{M} \mathrm{HCl}$ containing different concentrations of alkaloids extract of Retama monosperma stems after $6 \mathrm{~h}$ of immersion period at $30^{\circ} \mathrm{C}$
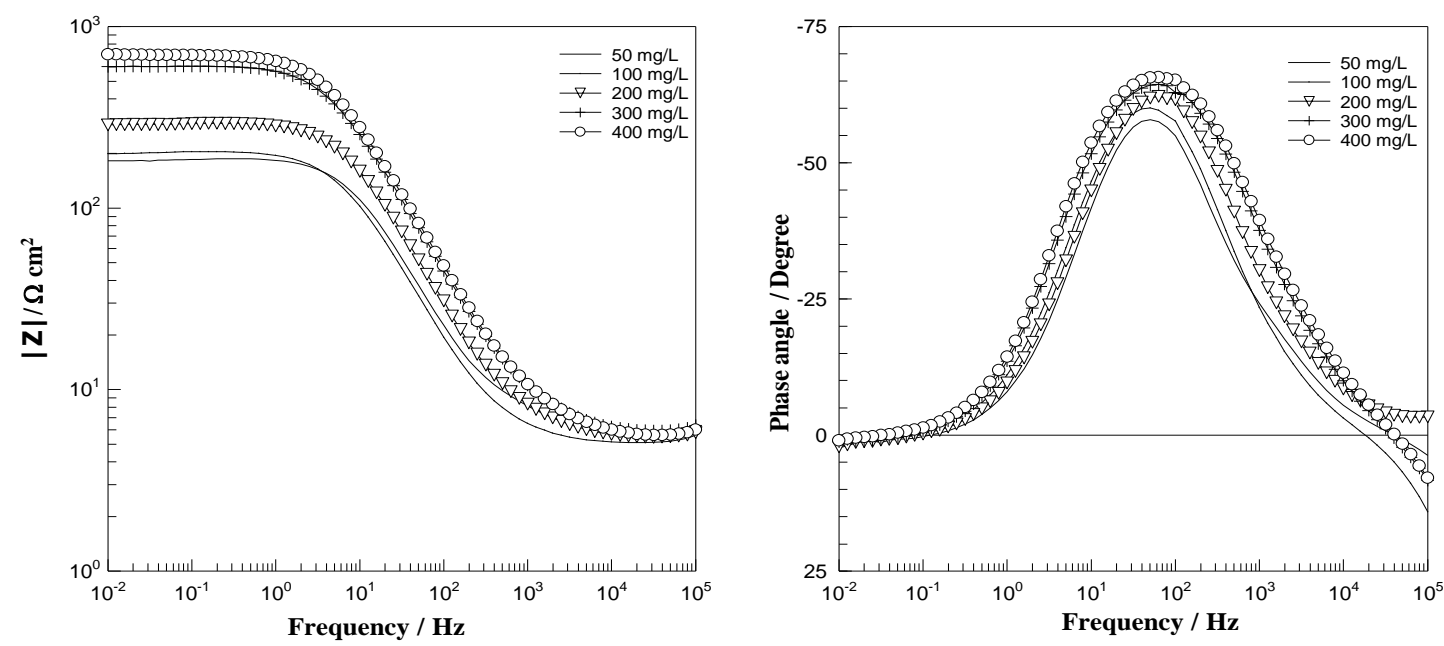

Figure 6: Bode (a- modulus and b- phase) diagrams for carbon steel in $1 \mathrm{M} \mathrm{HCl}$ containing different concentrations of AERST after $6 \mathrm{~h}$ of immersion period at $30^{\circ} \mathrm{C}$

In the studied frequency range, the system could be described by the corresponding structural model of the interface with DAPO, as shown in Fig. 7. In this equivalent circuit, $R_{\mathrm{S}}$ is the solution resistance, CPE is the constant phase elements for the double layer and is used instead of a pure capacitor to compensate for non-ideal capacitive response of the interface [25], and $R_{\mathrm{p}}$ is the polarization resistance, where $R_{\mathrm{p}}$ includes charge transfer resistance $\left(R_{\mathrm{ct}}\right)$ and the resistance of inhibitor film $\left(R_{\mathrm{f}}\right)$ formed on the metal surface in the presence of inhibitor $\left(R_{\mathrm{p}}=R_{\mathrm{ct}}+R_{\mathrm{f}}\right)[26]$.

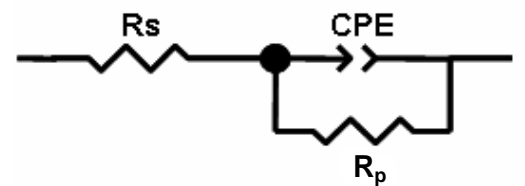

Figure 7: Electrical equivalent circuit used for modelling the interface carbon steel/HCl without and with AERST

The impedance $(Z)$ of the CPE is presented by [27]:

$Z_{\mathrm{CPE}}=Q^{-1}(i \omega)^{-n}$

Where $Q$ is the CPE constant (in $\Omega^{-1} \mathrm{~s}^{\mathrm{n}} \mathrm{cm}^{-2}$ ), $i$ is the imaginary number, $\omega$ is the angular frequency (in $\operatorname{rads}^{-1}$ ), and $n$ is CPE exponent, which can be used as a gauge heterogeneity or roughness of the surface.

The corresponding fitted parameters are listed in Table 3. The data are found to be sufficiently well fitted within the limits of experimental error and reproducibility of data. In the Table 4 are also given the calculated "double layer capacitance" values, $C_{\mathrm{dl}}$, derived from the CPE parameters, using the Hsu and Mansfeld formula [28]: 
$C \mathrm{dl}=\left(Q \cdot R_{\mathrm{p}}{ }^{1-\mathrm{n}}\right)^{1 / \mathrm{n}}$

And the time constant of the charge transfer process $(\tau)$, it is defined [29] as:

$\tau=C_{\mathrm{dl}} R_{\mathrm{p}}$

Table 3.Impedance parameters and inhibition efficiency values for carbon steel after $6 \mathrm{~h}$ immersion period in 1 $\mathrm{M} \mathrm{HCl}$ containing different concentrations of AERST at $30^{\circ} \mathrm{C}$.

\begin{tabular}{ccccccccc}
\hline & $\begin{array}{c}\text { Conc. } \\
(\mathrm{mg} / \mathrm{L})\end{array}$ & $\begin{array}{c}R_{\mathrm{s}} \\
\left(\Omega \mathrm{cm}^{2}\right)\end{array}$ & $\begin{array}{c}R_{\mathrm{p}} \\
\left(\Omega \mathrm{cm}^{2}\right)\end{array}$ & $\begin{array}{c}10^{4} Q \\
\left(\Omega^{-1} \mathrm{~s}^{\mathrm{n}} \mathrm{cm}^{-2}\right)\end{array}$ & $n$ & $\begin{array}{c}C_{\mathrm{dl}} \\
\left(\mu \mathrm{F} \mathrm{cm}{ }^{-2}\right)\end{array}$ & $\begin{array}{c}\tau \\
(\mathrm{s})\end{array}$ & $\begin{array}{c}\eta_{\mathrm{Z}} \\
(\%)\end{array}$ \\
\hline $1 \mathrm{M} \mathrm{HCl}$ & - & $5.68 \pm 0.04$ & $39.6 \pm 0.3$ & $2.64 \pm 0.11$ & $0.881 \pm 0.006$ & 142.5 & 0.0056 & - \\
\hline \multirow{4}{*}{ AERST } & 50 & $5.33 \pm 0.01$ & $63.3 \pm 0.1$ & $2.62 \pm 0.02$ & $0.823 \pm 0.003$ & 108.7 & 0.0067 & 37.4 \\
& 100 & $5.50 \pm 0.02$ & $174.3 \pm 0.6$ & $1.95 \pm 0.03$ & $0.829 \pm 0.004$ & 97.0 & 0.0169 & 77.3 \\
& 200 & $5.03 \pm 0.04$ & $176.5 \pm 1.3$ & $1.87 \pm 0.03$ & $0.828 \pm 0.003$ & 91.8 & 0.0162 & 77.6 \\
& 300 & $5.74 \pm 0.03$ & $219.9 \pm 1.8$ & $1.50 \pm 0.02$ & $0.829 \pm 0.004$ & 74.7 & 0.0164 & 82.0 \\
& 400 & $4.70 \pm 0.04$ & $227.5 \pm 1.9$ & $1.41 \pm 0.04$ & $0.839 \pm 0.002$ & 72.9 & 0.0166 & 82.6 \\
\hline
\end{tabular}

The inspection of the results in Table 3 shows that the $R_{\mathrm{p}}$ values increase with increasing concentration of AERST while the $C_{\mathrm{dl}}$ values for the inhibitor are generally lower than that of the acid blank, which suggest that the inhibitor adsorb on the steel surface thereby forming a protective layer on the steel surface and reducing the rate of charge transfer process. Also, the values of $Q$ are lower in the presence of AERST compared to that of uninhibited blank system. This can be attributed to gradual displacement of water molecules by inhibitor molecules at metal/solution interface leading to formation of protective layer on the steel surface. Concerning the phase shift $(n)$ behaviour, the obtained values (ranges from 0.823 to 0.839 ) decrease after addition of AERST in the corrosive solution, when compared to that obtained in pure $1 \mathrm{M} \mathrm{HCl}(0.881)$. This shows an increase of the surface inhomogeneity as a result of the inhibitor's adsorption [30]. Moreover, the value of the relaxation time constant $(\tau)$ slowly increases with AERST concentration as well and the time of adsorption process becomes therefore much higher which means a slow adsorption process [31,32]. In the same manner, a decrease in $C_{\mathrm{dl}}$ is attributed to decrease in dielectric constant and increase in the thickness of the electrical double layer, suggesting that the AERST molecules are adsorbed at the metal/solution interface [33]. This behaviour is in accordance with Helmholtz model, given by the following equation [34]:

$C_{\mathrm{dl}}=\frac{\varepsilon_{0} \varepsilon}{d} A$

Where $d$ is the thickness of the protective layer, $\varepsilon$ is the dielectric constant of the medium, $\varepsilon \circ$ is the vacuum permittivity and $A$ is the effective surface area of the electrode.

The inhibition efficiency in the case of AC impedance study, $\eta_{Z}(\%)$, was evaluated by $R_{\mathrm{p}}$ values as described previously [16. The calculated $\eta_{\mathrm{Z}}(\%)$ values are listed in Table 3 . As can be seen in Table 3, the corrosion inhibition efficiency, $\eta_{Z}(\%)$, increases continuously with increasing of the AERST inhibitor concentration and the maximum of $82.6 \%$ was achieved in the case of $400 \mathrm{mg} / \mathrm{L}$ after $6 \mathrm{~h}$ of immersion period (Table 3). It is worth mentioning that the corrosion inhibition efficiency values, $\eta(\%)$, calculated by the weight loss and AC impedance techniques are in reasonably agreement.

\subsection{Isotherm and surface studies}

In order to gain more information about the type of interaction between the AERST molecules and the steel surface, various adsorption isotherms (Temkin, Frumkin and Langmuir isotherm) were applied to fit the surface coverage $(\theta)$ values at different concentrations of AERST. According to these isotherms, $\theta$ is related to the inhibitor concentration $\left(C_{\mathrm{inh}}\right)$ via the following equations [35]:

$$
\begin{array}{ll}
\frac{C_{\mathrm{inh}}}{\theta}=\frac{1}{K_{\mathrm{ads}}}+C_{\mathrm{inh}} & \text { (Langmuir isotherm) } \\
\exp (-2 a \theta)=K_{\mathrm{ads}} C_{\mathrm{inh}} & \text { (Temkin isotherm) } \\
\left(\frac{\theta}{1-\theta}\right) \exp (2 a \theta)=K_{\mathrm{ads}} C_{\mathrm{inh}} & \text { (Frumkin isotherm) }
\end{array}
$$


where $\theta$ is the fractional surface coverage; $C_{\text {inh }}$ is the inhibitor concentration; $a$ is the molecular interaction constant; and $K_{\text {ads }}$ is the equilibrium constant of the adsorption process. The fractional surface coverage $\theta$ can be easily determined from AC impedance measurements by the ratio $\eta_{\mathrm{Z}}(\%) / 100$, if one assumes that the values of $\eta_{\mathrm{Z}}(\%)$ do no differ substantially from $\theta$ (the impedance data are collected in a time interval of $6 \mathrm{~h}$, considered sufficient for adsorption equilibrium to be achieved) [36].

To choose the isotherm that best fit to experimental data, the correlation coefficient $\left(R^{2}\right)$ was used and the best fit was obtained from the Langmuir isotherm (Figs. 8 and 9), which suggests that the adsorption process of AERST on carbon steel surface in $1 \mathrm{M} \mathrm{HCl}$ solution obeys to the Langmuir adsorption isotherm.

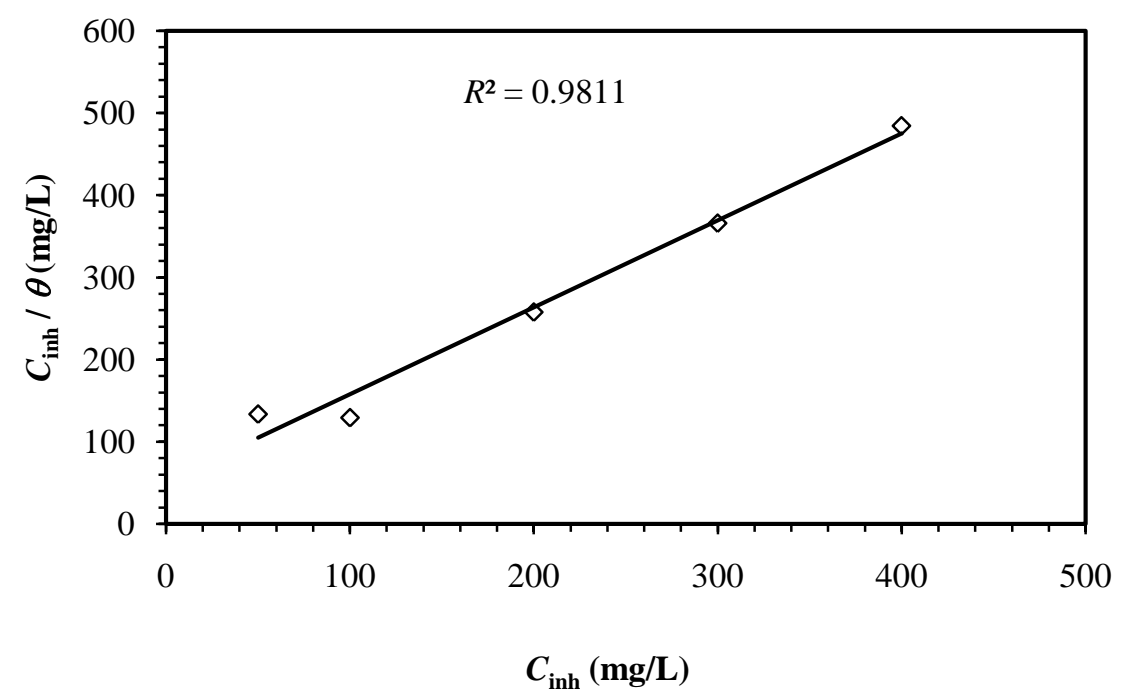

Figure 8: Langmuir's adsorption isotherm for carbon steel in $1 \mathrm{M} \mathrm{HCl}$ containing AERST at $30^{\circ} \mathrm{C}$

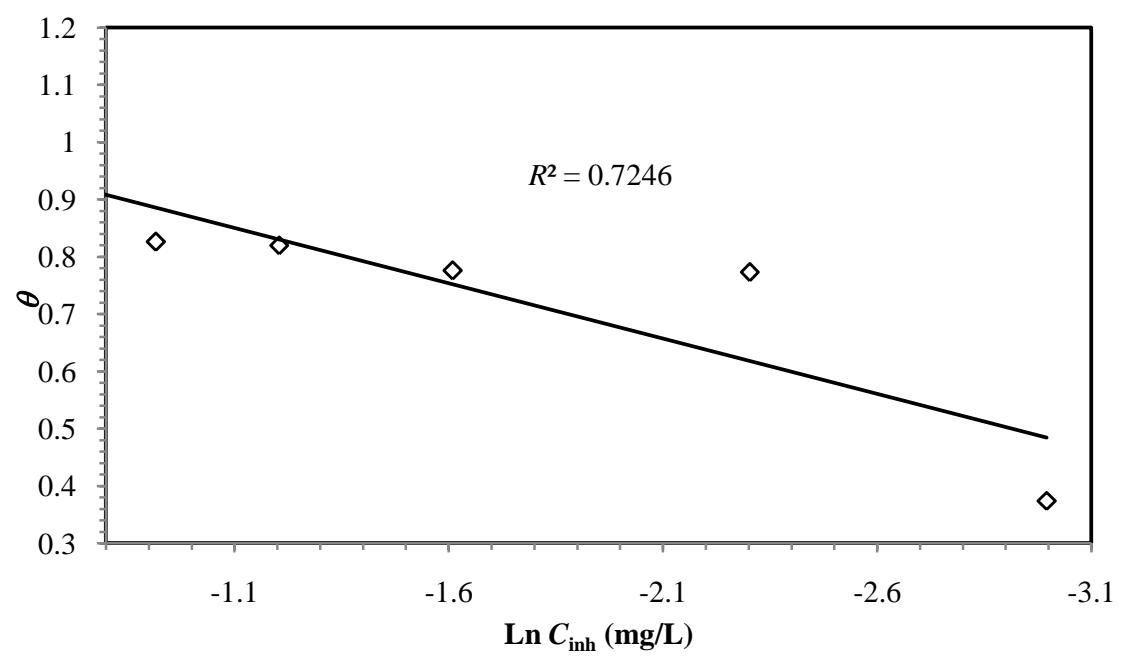

Figure 9: Temkin's adsorption isotherm for carbon steel in $1 \mathrm{M} \mathrm{HCl}$ containing AERST at $30^{\circ} \mathrm{C}$

To calculate the adsorption parameters, the straight line was drawn using the least squares method. The experimental (points) and calculated isotherm (line) were plotted in Fig. 8. A very good fit was observed with the regression coefficient up to 0.98 , which suggests that the experimental data are well described by Langmuir isotherm and exhibit single-layer adsorption characteristic. This kind of isotherm involves the assumption of no interaction between the adsorbed species on the electrode surface [37]. From the intercepts of the straight lines $C_{\text {inh }} / \theta$ - axis, the $K_{\text {ads }}$ value was calculated; $K_{\text {ads }}=19.21 \mathrm{~L} / \mathrm{g}$. $K_{\text {ads }}$ is related to the standard Gibbs free energy of adsorption, $\Delta G_{\text {ads, }}^{\circ}$ according to [31]:

$$
K_{\text {ads }}=\frac{1}{C_{\mathrm{H}_{2} \mathrm{O}}} \exp \left(\frac{-\Delta G_{\text {ads }}^{\mathrm{o}}}{R T}\right)
$$

Where $R$ is the universal gas constant, $T$ the thermodynamic temperature and the concentration of water in the solution is $1000 \mathrm{~g} / \mathrm{l}$.

As the natural extract contains infinite components at various contents and the majority contains one and/or more than function group as ketone, alcohol, acid, aldehyde..., the inhibitory effect is generally interpreted by 
the intermolecular synergistic effect of several molecules [38]. Therefore, the adsorption mechanism of AERST on carbon steel in $1 \mathrm{M} \mathrm{HCl}$ solution at $30^{\circ} \mathrm{C}$ is mainly electrostatic-adsorption (ionic). In order to confirm this assumption (physisorption) and elucidate the nature of the organic thin film formed on the steel surface, the surface analyses (XPS) are given and discussed in the next section.

X-ray photoelectron spectroscopy (XPS) analyses were carried out on, the carbon steel surface after six hours of immersion in the corrosive solution containing $400 \mathrm{mg} / \mathrm{L}$ of AERST d(at this concentration, the highest inhibition efficiency was achieved as shown previously). The obtained XPS spectra (Fe $2 p, \mathrm{Cl} 2 p, \mathrm{O} 1 s$, and C $1 s$ ), given in Fig. 10, show complex forms, which were assigned to the corresponding species through a deconvolution fitting procedure. The binding energies $(\mathrm{BE}, \mathrm{eV})$ and the corresponding quantification $(\%)$ of each peak component are summarised in Table 4.

The Fe $2 p$ spectrum for carbon steel surface covered with AERST depicts a double peak profile located at a binding energy $(\mathrm{BE})$ around $711 \mathrm{eV}\left(\mathrm{Fe} 2 p_{3 / 2}\right)$ and $725 \mathrm{eV}\left(\mathrm{Fe} 2 p_{1 / 2}\right)$ together with an associated ghost structure on the high energy side showing the subsequent oxidation of the steel surface. The deconvolution of the high resolution Fe $2 p_{3 / 2}$ XPS spectrum consists in three peaks at 706.7, 710.4, and 714.1 eV (Fig. 10a, Table 4). The peak at lower bending energy $(707.2 \mathrm{eV})$ is attributed to metallic iron as previously reported [39], while that at $711.1 \mathrm{eV}$ assigned to $\mathrm{Fe}^{3+}$ as mentioned in [40], is associated to ferric oxide/hydroxide species such as $\mathrm{Fe}_{2} \mathrm{O}_{3}$, $\mathrm{Fe}_{3} \mathrm{O}_{4}$ and $\mathrm{FeOOH}$ [41]. The last peak at $713.9 \mathrm{eV}$ was partly ascribed to the satellite of $\mathrm{Fe}(\mathrm{III})$ [42] and partly related to the presence of a small concentration of $\mathrm{FeCl}_{3}$ on the steel surface due to the testing environment $[43,44]$. Indeed, the signal of $\mathrm{Cl} 2 p$ was observed on the steel surface in presence of inhibitor (Fig. 10b, Table 4 ), but the low intensity of $\mathrm{Cl} 2 p$ peak reflects the presence of small chloride content on the steel surface. This former can be attributed to $\mathrm{Cl}-\mathrm{Fe}$ bond in $\mathrm{FeCl}_{3}$ as mentioned previously [43]. The $\mathrm{O} 1 s$ spectrum for carbon steel surface after immersion in $1 \mathrm{M} \mathrm{HCl}$ solution containing AERST may be fitted into three main peaks at 530.2, 531.7, and 533.1 eV (Fig. 10c, Table 4). The first two peaks correspond to the binding energy of the $\mathrm{O}^{2-}$ and $\mathrm{OH}^{-}$ions [45], in agreement with the presence of the iron oxide/hydroxide layer as detected in the Fe $2 p_{3 / 2}$ spectrum. The third peak at $532.7 \mathrm{eV}$ may be assigned to oxygen of adsorbed water [46]. However, it is not possible to separate contributions of organic oxygen ( $\mathrm{O}$ in carbonyl) since $\mathrm{O} 1 \mathrm{~s}$ signal [47]. Therefore, the signals at $531.7 \mathrm{eV}$ and $533.1 \mathrm{eV}$ may be also attributed to oxygen double bonded to carbon $(\mathrm{C}=\mathrm{O})$ which are present in some AERST molecules as given in Fig. 1 [48]. This finding is in agreement with the $\mathrm{C} 1 s$ region, where peaks due to $\mathrm{C}-\mathrm{H}, \mathrm{C}-\mathrm{C}, \mathrm{C}=\mathrm{C}, \mathrm{C}-\mathrm{O}$ and $\mathrm{C}=\mathrm{O}$ bonds were obtained. Indeed, the corresponding $\mathrm{C} 1 \mathrm{~s}$ spectrum can be deconvoluted into three components with different intensities (Fig. 10d, Table 4). The first and most intense, at $284.9 \mathrm{eV}$, is mainly attributed to the presence of contaminant hydrocarbons and to the $\mathrm{C}-\mathrm{C}$, $\mathrm{C}=\mathrm{C}$ and $\mathrm{C}-\mathrm{H}$ bonds related to the different constituents of AERST [49]. The second component at $286.5 \mathrm{eV}$ may be associated with the presence of $\mathrm{C}=\mathrm{O}$ groups in the AERST molecules (Ammodendrine, Anagyrine, $\mathrm{N}$ methylcytisin...) [50]. The last component at higher binding energy $(288.7 \mathrm{eV})$ can be also associated with the presence of carbonyl type groups and/or probably due to the $\mathrm{C}-\mathrm{N}^{+}$[51], resulting from the protonation of the nitrogen atoms in the AERST molecules.

The adsorption of AERST on the steel surface can be explained especially by the presence of the $\mathrm{N} 1 s$ peak in the survey (not given). Indeed, the investigated carbon steel doesn't contain the nitrogen and the $\mathrm{N} 1 s$ spectrum of untreated carbon steel, previously described [52], confirms the absence of the nitrogen in this substrate. The deconvolution of the $\mathrm{N} 1 s$ spectrum of AERST-treated carbon steel revealed three components (Fig. 10e, Table 4). The first component, located at $397 \mathrm{eV}$, can be assigned to $\mathrm{N}-\mathrm{C}$ (pyrrole-like, $=\mathrm{N}-$ structure) [53]. The second component, located at $400.2 \mathrm{eV}$, can be attributed to $\mathrm{N}$ atoms in pyrrole-like and $=\mathrm{N}-$ structure connected to the carbon steel substrate. The last component (centered at $402.1 \mathrm{eV}$ ) can be ascribed to the positively charged nitrogen, and is consistent with protonated nitrogen atoms $\left(-\mathrm{N}^{+} \mathrm{H},=\mathrm{N}^{+}-\mathrm{H}\right)$ in the AERST derivatives [54]. However, the lower nitrogen content $(1.4 \%)$ on the steel surface provides a possible answer concerning the mode of AERST adsorption, suggesting that $\mathrm{N}$ atoms in the AERST molecules are not involved in the surface bonding with the steel substrate. This $\mathrm{N} 1 s$ XPS result can suggest that AERST molecules were electrostatically adsorbed on the steel surface.

The XPS results provide direct evidence of the adsorption of the AERST molecules onto carbon steel surface and corroborate the thermodynamic study. Furthermore, the comparison of the Fe2 $p_{3 / 2}$ XPS results for carbon steel after immersion in $1 \mathrm{M} \mathrm{HCl}$ medium containing AERST with that for untreated surface steel, previously described [52], shows that the corrosive solution induces a significant decrease in $\mathrm{Fe}^{0}$ amount in favour of oxidized species, specially $\mathrm{Fe}^{3+}$, indicating therefore that the oxide layer thickness is increasing. Indeed, the addition of stems extract (AERST) in the corrosive solution promotes the formation of a stable and insoluble oxide layer $\left(\mathrm{Fe}_{2} \mathrm{O}_{3}, \mathrm{FeOOH}\right)$ that can reduce ions diffusion, and therefore improves the corrosion resistance of carbon steel in $1 \mathrm{M} \mathrm{HCl}$ medium. 

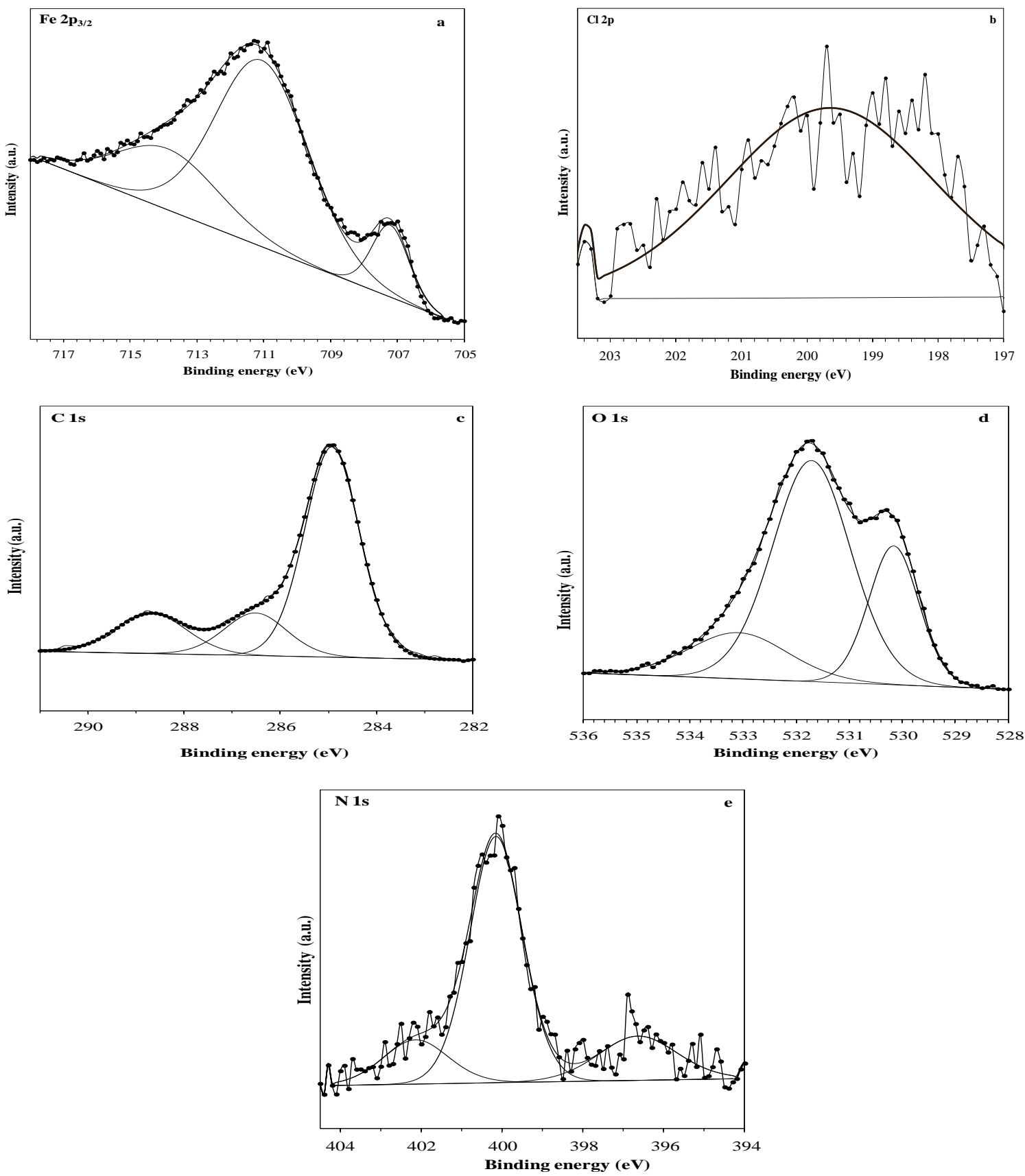

Fig. 10: The XPS deconvoluted profiles of a- $\mathrm{C} 1 s, \mathrm{~b}-\mathrm{N} 1 s, \mathrm{c}-\mathrm{O} 1 s$ and d- Fe $2 p_{3 / 2}$ for AERST treated carbon steel

Table 4. Binding energies $(\mathrm{eV})$, relative intensity and their assignment for the major core lines observed for AERST treated carbon steel surface.

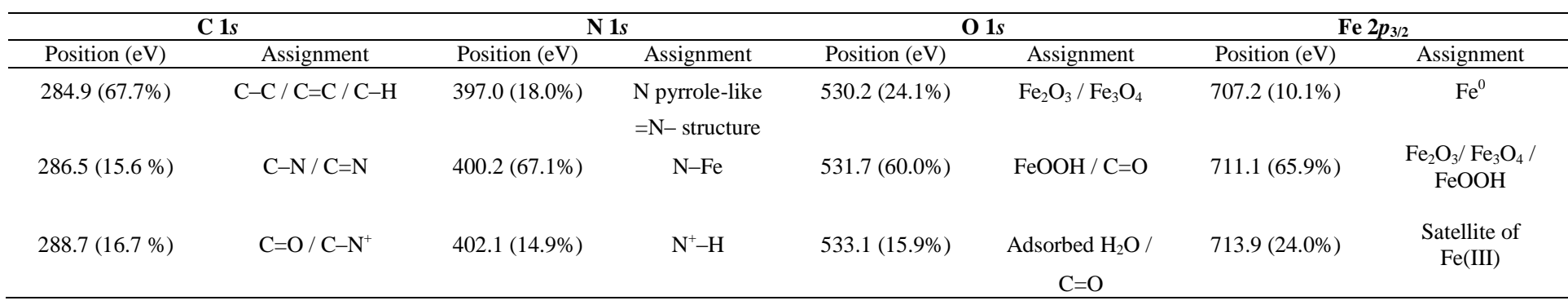

\subsection{Comparison of Retama monosperma extracts (stems and seeds)}

We have described recently the use of alkaloids extract from Retama monosperma seeds (AERS) as carbon steel corrosion inhibitor in $1 \mathrm{M} \mathrm{HCl}$ medium [16]. Fig. 8 shows the percentage inhibition efficiency, obtained using AC impedance measurements, for the stems extract (AERST) (this work) and the seeds extract (AERS) [16]. By 
comparing these data, we can show that AERS (seeds extract) is more effective than AERST (stems extract). The difference in the inhibitive performance between the seeds and stems extracts can be explained by their compositions. Indeed, the studies on the phytochemical constituents of Retama monosperma (L.) Boiss. extracts (seeds and stems) show that the seeds extract contains $N$-methylcytisine $(13 \%)$, dehydro-cytisine $(9.40 \%)$ and cytisine $(77.60 \%)$ and the stems extract contains ten molecules (see Table 1). Inspection of the two extract compositions indicated that the seeds extract contains only the cytisine derivatives and the percentages are higher in the seeds than in the stems especially of cytisine and $N$-methylcytisine. The high inhibitive performance of the seeds extract can be related to the presence of cytisine derivatis, which posses many lone pairs from heteroatom (oxygen, nitrogen) and $\pi$-orbitals, blocking the active sites and therefore decreasing the corrosion rate steel substrate. However, further investigation to isolate the active ingredients (cytisine) and test their inhibition ability is being carried out in our laboratories in order to confirm this assumption.

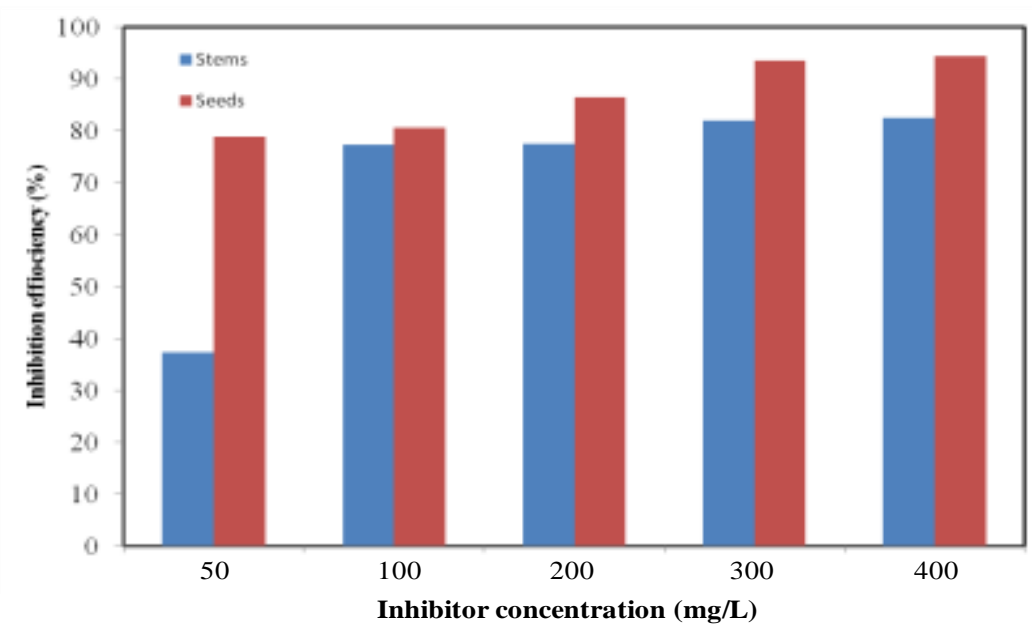

Figure 11: Comparison of inhibition efficiency of alkaloids extract of Retama monosperma stems (AERST) and alkaloids extract of Retama monosperma seeds (AERS)

\section{Conclusions}

The present study shows that the alkaloids extract from Retama monosperma stems (AERST) can be used as green corrosion inhibitor for the carbon steel in $1 \mathrm{M} \mathrm{HCl}$ acid solution. Weight-loss data give evidence that the inhibition efficiency of AERST increased on increasing the inhibitor concentration reaching value up to $83.1 \%$ at $400 \mathrm{mg} / \mathrm{L}$. SEM indicated that the surface morphology shown in presence of AERST is significantly different and more regular than that obtained in $1 \mathrm{M} \mathrm{HCl}$ solution without inhibitor. The impedance results indicate that the value of charge-transfer resistance $\left(R_{\mathrm{ct}}\right)$ increased and double layer capacitance $\left(C_{\mathrm{dl}}\right)$ decreased. This result can be attributed to the increase of thickness of electrical double layer. A very good agreement between results obtained by weight-loss measurements and AC impedance was demonstrated. The adsorption of AERST was successfully described by the Langmuir adsorption isotherm and the corresponding value of $\Delta G^{\circ}$ ads revealed that the adsorption mechanism of this inhibitor on carbon steel surface in $1 \mathrm{M} \mathrm{HCl}$ solution is mainly due to physisorption. XPS analysis confirmed the adsorption of for the stems extract on carbon steel surface and showed that the protective film is composed by an iron oxide/hydroxide stable layer in which the AERST molecules are incorporated, blocking therefore the active sites of the steel surface.

Acknowledgements: The authors gratefully acknowledge the CUR CA2D of Chouaib Doukkali University (El Jadida-Morocco) for its support.

\section{References}

1. P.B. Raja, M.G. Sethuraman, Mater. Lett. 62 (2008) 113.

2. M. Lebrini, F. Robert, A. Lecante, C. Roos, Corros. Sci. 53 (2011) 687.

3. M. Lebrini, F. Robert, C. Roos, Int. J. Electrochem. Sci. 6 (2011) 847.

4. F. ElHajjaji, H. Greche, M. Taleb, A. Chetouani, A. Aouniti, B. Hammouti, J. Mater. Environ. Sci. 7 (2016) 567-578

5. M. Lebrini, F. Robert, C. Roos, Int. J. Electrochem. Sci. 5 (2010) 1698.

6. M. Faustin, M. Lebrini, F. Robert, C. Roos, Int. J. Electrochem. Sci. 6 (2011) 4095.

7. M. Znini, L. Majidi, A. Bouyanzer, J. Paolini, J.-M. Desjobert, J. Costa, B. Hammouti, Arabian Journal of Chemistry, 5 (2012) 467-474

8. A. Singh, E.E. Ebenso, M.A. Quraishi, Int. J. Corros. 2012 Article ID 897430 (and references therein). 
9. A. El Bribri, M. Tabyaoui, B. Tabyaoui, H. El Attari, F. Bentiss, Mat. Chem. Phys. 141 (2013) 240.

10. K. Boumhara, F. Bentiss, M. Tabyaoui, J. Costa, J.-M. Desjobert, A. Bellaouchou, A. Guenbour, B. Hammouti, S.S. Al-Deyab, Int. J. Electrochem. Sci. 9 (2014) 1187.

11. K. Boumhara, M. Tabyaoui, C. Jama, F. Bentiss, J. Ind. Eng. Chem. 29 (2015) 146.

12. P.C. Okafor, V.I. Osabor, E.E. Ebenso, Pigm. Res. Technol. 35 (2007) 299.

13. V.U. Khuzhaeu, S.F. Aripova, Chem. Nat. Compd. 36 (2000) 418.

14. A.U. Ogan, Phytochem. Rep. 99 (1971) 441.

15. P.C. Okafor, U.J. Ekpe, E.E. Ebenso, E.M. Umoren, K.E. Leizou, Bull. Electrochem. 21 (2005) 347.

16. N. El Hamdani, R. Fdil, M. Tourabi, C. Jama, F. Bentiss, App. Surf. Sci. 357 (2015) 1294.

17. R. Fdil, N. El Hamdani, A. El Kihel, K. Sraidi, Ann. Toxicol. Anal. 24 (2012) 139.

18. ASTM, G 31-72, American Society for Testing and Materials Philadelphia, PA,1990.

19. M. El Belghiti, Y. Karzazi, Dafali A., B. Hammouti, F. Bentiss, I.B. Obot, I. Bahadur, E.E. Ebenso, J. Mol. Liq. 218 (2016) 281.

20. D.A. Shirley, Phys. Rev. B 5 (1972) 4709.

21. H. Shih, F. Mansfeld, Corros. Sci. 29 (1989) 1235.

22. I.D. Raistrick, D.R. Franceschetti, J.R. Macdonald, Impedance spectroscopy, in:E. Barsoukov, Macdonald (Eds.) J.R., Theory, Experimental and Applications, second ed., John Wiley \& Sons, New Jersey, 2005.

23. T. Zhihua, Z. Shengtao, L. Weihua, H. Baorong, Ind. Eng. Chem. Res. 50 (2011)6082-6088.

24. A.O. Yüce, G. Kardas, Corros. Sci. 58 (2012) 86.

25. A. Popova, M. Christov, A. Vasilev, Corros. Sci. 53(2011) 1770.

26. B. Ramezanzadeh, S.Y. Arman, M. Mehdipour, B.P. Markhali, Appl. Surf. Sci. 289 (2014) 129.

27. D.A. Lopez, S.N. Simison, S.R. deSanchez, Electrochim. Acta 48 (2003) 845.

28. S. Martinez, M. Metikoš-Huković, J. Appl. Electrochem. 33 (2003) 1137.

29. H. Ma, X. Cheng, S. Chen, Z. Quan, S. Zhao, L. Niu, Corros. Sci. 42 (2000) 1669.

30. F.B. Growcock, R.J. Jasinski, J. Electrochem. Soc. 136 (1989) 2310.

31. M.S. Morad, Corros. Sci. 50 (2008) 436.

32. M. Lebrini, F. Bentiss, N. Chihib, C. Jama, J.P. Hornez, M. Lagrenée, Corros. Sci. 50 (2008) 2914.

33. M. Lebrini, M. Lagrenée, H. Vezin, M. Traisnel, F. Bentiss, Corros. Sci. 49(2007) 2254.

34. C.H. Hsu, F. Mansfeld, Corrosion 57 (2001) 747.

35. M. Faustin, A. Maciuk, P. Salvin, C. Roos, M. Lebrini, Corros. Sci. 92 (2015) 287.

36. J. de Damborenea, J.M. Bastidas, A.J. Vázquey, Electrochim. Acta. 42 (1997) 455.

37. M. Elayyachy, A. El Idrissi, B. Hammouti, Corros. Sci. 48 (2006) 2470.

38. I. Y. Suleiman, S. A. Yaro, M. Abdulwahab, Sani A. Salihu, O.C Ogheneme, J. Mater. Environ. Sci. 8 (2017) 3423-3432

39. V. Di castro, S. Ciampi, Surf. Sci. 331 (1995) 294.

40. N. Nakayamaand, A. Obuchi, Corros. Sci. 45 (2003) 2075.

41. F.Z. Bouanis, F. Bentiss, M. Traisnel, C. Jama, Electrochim. Acta 54 (2009) 2371.

42. A. Galtayries, R. Warocquier-Clérout, M.-D. Nagel, P. Marcus, Surf. Interface Anal. 38 (2006) 186.

43. F. Moulder, W.F. Stickle, P.E. Sobol, K.D. Bomben, in: J. Chastain (Ed.), Handbook of X-Ray Photoelectron Spectroscopy, Perkin-Elmer Corp., Minnesota, USA, 1992.

44. V.S. Sastri, M. Elboujdaini, J.R. Romn, J.R. Perumareddi, Corrosion 52 (1996) 447.

45. P. Bommersbach, C. Alemany-Dumont, J.P. Millet, B. Normand, Electrochim. Acta 51 (2005) 1076.

46. K. Babić-Samardžija, C. Lupu, N. Hackerman, A.R. Barron, A. Luttge, Langmuir 21 (2005) 12187.

47. A.R. González-Elipe, A. Martínez-Alonso, J.M.D. Tascón, Surf. Interface Anal. 12(1988) 565.

48. A.G. Kannan, N.R. Choudhury, N.K. Dutta, Polymer 48 (2007) 7078.

49. D. Briggs, M.P. Seah, Practical Surface Analysis by Auger and X-ray Photoelectron Spectroscopy, John Wiley \& Sons Ltd., Sussex, 1983 (Section 9.4 and Appendix 2).

50. S.R. Kelemen, M. Afeworki, M.L. Gorbaty, Energy Fuels. 16 (2002) 1450.

51. J.F. Watts, J. Wolstenholme, An Introduction to Surface Analysis by XPS andAES, John Wiley and Sons Inc., UK, 2003.

52. F.Z. Bouanis, F. Bentiss, S. Bellayer, M. Traisnel, J.B. Vogt, C. Jama, Mater. Chem. Phys. 127 (2011) 329.

53. P. Morales-Gil, M.S. Walczak, R.A. Cottis, J.M. Romero, R. Lindsay, Corros. Sci. 85 (2014) 109.

54. G.A. Schick, Z.Q. Sun, Langmuir. 10 (1994) 3105.

(2018) ; http://www.jmaterenvironsci.com 